\title{
Inhibitory Activity of Leaves Extracts of Citrullus colocynthis Schrad. On HT29 Human Colon Cancer Cells
}

\author{
Belsem Marzouk ${ }^{1}$, Francesca Mussi ${ }^{2}$, Chaima Alaoui Jamali ${ }^{3}$, Serena Galati ${ }^{2}$, \\ Khalid Bekkouche ${ }^{3}$, Mahjoub Aouni ${ }^{1}$, Laura Arru ${ }^{4,5}$, Zohra Marzouk ${ }^{6}$ \\ and Annamaria Buschini ${ }^{*}$ \\ ${ }^{1}$ Laboratoire des Maladies Transmissibles et Substances Biologiquement Actives, \\ Faculté de Pharmacie, Monastir, Rue Avicenne 5000 Monastir, Tunisie. \\ ${ }^{2}$ Department of Life Sciences, University of Parma, Parco Area delle Scienze 11/A, \\ 43124 Parma, Italy. \\ ${ }^{3}$ Laboratoire Biotechnologies, Protection et Valorisation des Ressources Végétales, Equipe \\ Phytochimie et Pharmacologie des Plantes Aromatiques et Médicinales, Département de Biologie, \\ Faculté des Sciences-Semlalia, BP: 2390, 40000, Marrakech, Morocco. \\ ${ }^{4}$ Department of Life Sciences, University of Modena and Reggio Emilia, Via Amendola 2, \\ 42122 Reggio Emilia, Italy. \\ ${ }^{5}$ Unité de Pharmaco-économie et Développement des Médicaments, Laboratoire de Biologie \\ Végétale et Laboratoire de Pharmacologie, Faculté de Pharmacie, 5000 Monastir, Tunisie. \\ ${ }^{6}$ Interdepartmental Research Centre Biogest-Siteia, via Amendola 2, 42122 Reggio Emilia, Italy.
}

Authors' contributions

This work was carried out in collaboration between all authors. Authors $A B, B M$ and $F M$ designed the study, performed the statistical analysis, wrote the protocol and wrote the first draft of the manuscript.

Authors BM, FM, CAJ, SG, KB, LA and ZM managed the analyses of the study and the literature searches. Author $A B$ had primary responsibility for the final content. All authors read and approved the final manuscript.

Article Information

DOI: $10.9734 / E J M P / 2016 / 22888$

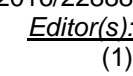

Complete Peer review History:

Original Research Article

Received $3^{\text {rd }}$ November 2015 Accepted $10^{\text {th }}$ December 2015 Published $30^{\text {th }}$ January 2016 


\section{ABSTRACT}

Aims: Citrullus colocynthis is a plant endemic in Asia, Africa and in the Mediterranean basin. It is used in folk medicine against infections, inflammations and cardiovascular and immune-related diseases. There are further evidences of the use of Citrullus colocynthis Schrad in the treatment of cancer in traditional practices. The present study aimed to determine the potential antiproliferative effects of different Citrullus colocynthis leaf extracts on human cancer cells.

Methodology: Antiproliferative and antioxidant effects on HT-29 human colon cancer cells were detected by MTS assay and a modified protocol of the alkaline Comet assay. In vitro antioxidant activities of different leaf extracts were evaluated through DPPH, $\beta$-carotene/linoleic acid and reducing power assays.

Results: The leaf chloroform extract exhibited the higher cell growth inhibitory activity without induction of DNA damage; it showed to be able to significantly decrease DNA damage induced by $\mathrm{H}_{2} \mathrm{O}_{2}(100 \mu \mathrm{M})$. This antioxidant activity seems to be comparable to that of vitamin $\mathrm{C}(1 \mathrm{mM})$. Ethyl acetate, acetone and methanol leaf extracts showed to be the most effective in reducing the stable free DPPH radical $\left(\mathrm{IC}_{50}=113 \mu \mathrm{g} / \mathrm{ml}\right)$, in transforming the $\mathrm{Fe}^{3+}$ to $\mathrm{Fe}^{2+}\left(\mathrm{IC}_{50}=134 \mu \mathrm{g} / \mathrm{ml}\right)$ and in inducing linoleic acid oxidation with an inhibition of $31.9 \%$.

Conclusion: Our results confirm the antiproliferative potential of Citrullus colocynthis Schrad. on human cancer cells.

Keywords: Antiproliferative; DNA damage; antioxidant; DPPH assay, $\beta$-carotene/linoleic acid assay; reducing power assay.

\section{INTRODUCTION}

Citrullus colocynthis Schrad. (cucurbitaceae), is a desert plant native to the Mediterranean basin and Asia. It is a medicinal plant widely used in the folk medicine of these areas for treatment of many diseases such as rheumatisms, hypertension, dysentery, diabetes, dermatological problems and gynaecological or pulmonary infections [1,2]. Moreover, there are evidences of the use of fruits [1] or of a combination of Citrullus colocynthis Schrad flowers, leaves and roots in the treatment of cancer [2].

Citrullus colocynthis Schrad. contains cucurbitacins glucosides, terpens predominantly found in the cucurbitaceae family. The cucurbitacins have demonstrated many biological effects, such as immunostimulant [3], antimicrobial [4], antioxidant, analgesic and antiinflammatory [5-7] properties, and efficient activities against hepatic diseases [8] and hyperglycaemia [9]. In addition, cucurbitacins have shown a growth inhibitory activity on cancer cells through different mechanisms $[10,11]$. Since the presence of cucurbitacins along with other biologically active molecules may explain the efficacy of Citrullus colocynthis Schrad. in the treatment of cancer, scientific studies are needed to support this idea. Thereafter, the aim of our study was to evaluate the ability of different extracts of Citrullus colocynthis Schrad. leaves to induce cell growth inhibition on a human colon cancer cell line (HT29). Since the oxidative stress can lead to inhibition of the proliferation, we evaluated the in vitro antioxidant effect of the leaf extracts and, for the chloroform extract, which proved to be the most antiproliferative one, we evaluated the genotoxic and antioxidant activity on the HT29 cell line.

To the best of our knowledge, comparisons between in-vitro and cell-based antioxidant assays on Citrullus colocynthis Schrad. leaf extracts have never been reported.

\section{MATERIALS AND METHODS}

\subsection{Plant Material}

Citrullus colocynthis Schrad. leaves were collected in August 2007 from nearby Medenine village, El-Araidha region, Sidi Makhlouf municipality, Tunisia. The taxonomic identification of the plant material was confirmed by a plant taxonomist, Marzouk, Z., in the biological laboratory of the Faculty of Pharmacy of Monastir-Tunisia- according to the flora of Tunisia [12]. A voucher specimen (C.C-01.01) has been deposited in this laboratory.

\subsection{Preparation of Extracts}

Collected plant materials were dried; the leaves were separated from the stems and ground in a 
grinder with a $2 \mathrm{~mm}$ mesh. Different solvents in ascending polarity (petroleum ether, chloroform, ethyl acetate, acetone and methanol) were used for Soxhlet extraction to fractionate the soluble compounds from the leaves. The extraction was performed with dried powder placed inside a thimble made by thick filter paper, loaded into the main chamber of the Soxhlet extractor, which consisted of an extracting tube, a glass balloon and a condenser. The total extracting time was 6 $h$ for each solvent continuously refluxing over the sample. The resulting extracts were evaporated at reduced pressure to obtain the crude extracts.

\subsection{In vitro Antioxidant Activity}

\subsubsection{DPPH assay}

The in vitro antioxidant activity of Citrullus colocynthis Schrad. leaf extracts and control substances was measured in terms of hydrogendonating or radical-scavenging ability, using the stable radical 2,2-diphenyl-1-picrylhydrazyl (DPPH) as a reagent [13]. Fifty microliters of various concentrations of the sample in methanol (leaf extracts and control substances) were added to $2 \mathrm{ml}$ of a $60 \mu \mathrm{M}$ methanolic solution of $\mathrm{DPPH}$. Absorbance measurements were read at $517 \mathrm{~nm}$, after $20 \mathrm{~min}$ of incubation time at room temperature. The percentage inhibition of the $\mathrm{DPPH}$ radical by the samples was calculated according to the formula: IP $(\%)=$ $\left(A_{\text {blank }}-A_{\text {sample }} / A_{\text {blank }}\right) \times 100$; where $A_{\text {blank }}$ is the absorbance of the control reaction (containing all reagents except the test compound), and $A_{\text {sample }}$ is the absorbance of the test compound. Extract concentration providing $50 \%$ inhibition $\left(\mathrm{IC}_{50}\right)$ was calculated by plotting inhibition percentage against extract concentration. Synthetic antioxidant reagents $\mathrm{BHT}$ and quercetine were used as a positive control and all tests were carried out in triplicate and were reported as means \pm Standard Deviation (SD).

\subsubsection{Reducing power determination}

The reductive potential of the Citrullus colocynthis leaf extracts and of the standards (BHT and quercetine) was determined according to the method of Oyaizu [14]. The different methanolic samples were mixed with phosphate buffer (2.5 ml, 0.2 M, pH 6.6) and potassium ferricyanide $\left(\mathrm{K}_{3} \mathrm{Fe}(\mathrm{CN})_{6} ; 2.5 \mathrm{ml}, 1 \%\right)$. The mixture was then incubated at $50^{\circ} \mathrm{C}$ for $20 \mathrm{~min}$. Afterwards $2.5 \mathrm{ml}$ of trichloroacetic acid (10\%) was added to the mixture, which was then centrifuged for $10 \mathrm{~min}$ at $3000 \mathrm{rpm}$. Finally, the upper layer of solution $(2.5 \mathrm{ml})$ was mixed with distilled water $(2.5 \mathrm{ml})$ and $\mathrm{FeCl}_{3}(0.5 \mathrm{ml}, 0.1 \%$ $w / v)$, and the absorbance was measured at 700 $\mathrm{nm}$. Increased absorbance of the reaction mixture indicate increased reducing power. The assay was carried out in triplicate and $\mathrm{IC}_{50}$ were reported as means $\pm S D$.

\subsection{3 $\beta$-Carotene / linoleic acid bleaching assay}

The $\beta$-carotene/linoleic acid test evaluates the inhibitory effect of a compound or a mixture on the oxidation of $\beta$-carotene in the presence of molecular oxygen $\left(\mathrm{O}_{2}\right)$. The amount of the remained $\beta$-carotene gives an estimation of the antioxidant potential of the sample.

The method described by Miraliakbari [15] was used with minor modifications. A mixture of $\beta$-carotene and linoleic acid was prepared by mixing $0.5 \mathrm{mg} \beta$-carotene in $1 \mathrm{ml}$ chloroform (HPLC grade), $25 \mu$ linoleic acid and $200 \mathrm{mg}$ Tween 40. The chloroform was then completely evaporated under vacuum and $100 \mathrm{ml}$ of oxygenated distilled water was subsequently added to the residue and mixed gently to form a clear yellowish emulsion. The extracts and positive controls (BHT and quercetine) were individually dissolved in methanol $(2 \mathrm{~g} / \mathrm{l})$ and 350 $\mu \mathrm{l}$ of each of them were added to $2.5 \mathrm{ml}$ of the above emulsion in test tubes and mixed thoroughly. The test tubes were incubated in a water bath at $50^{\circ} \mathrm{C}$ for $2 \mathrm{~h}$. Negative control (blank) contained only methanol. The absorbance values were measured at $470 \mathrm{~nm}$ through an ultraviolet and visible (UV-Vis) spectrometer. Antioxidant activities (inhibition percentage, IP \%) of the samples were calculated using the following equation: IP \% =

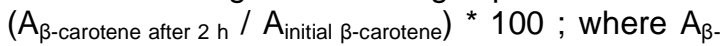
carotene after $2 \mathrm{~h}$ is the absorbance values of $\beta$ carotene after $2 \mathrm{~h}$ assay and $\mathrm{A}_{\text {initial } \beta \text {-carotene }}$ is the absorbance value of $\beta$-carotene at the beginning of the experiment.

All tests were carried out in triplicate and inhibition percentages were reported as means \pm SD.

\subsection{Biological Activities on HT-29 Cells}

\subsubsection{Maintenance of cell line}

For in vitro cellular studies we employed the human colon adenocarcinoma cell line HT-29, used widely as a model for colon cancer. 
The HT-29 cell line, kindly obtained from the Northern Ireland Center for Food and Health, was maintained in $25 \mathrm{~cm}^{2}$ flasks with $5 \mathrm{ml}$ of Dulbecco's Modified Eagle Media (DMEM) supplemented with $10 \%$ foetal bovine serum (FBS), $1 \%$ L-glutamine and $0.5 \%$ penicillin/streptomycin in a humidified atmosphere containing $5 \% \mathrm{CO}_{2}$ at $37^{\circ} \mathrm{C}$ in an incubator. Every 3 days the cells were subcultured by splitting the culture with fresh medium.

\subsubsection{Antiproliferative effect}

The antiproliferative activities of leaf extracts was measured by MTS assay (Promega, Madison, WI) [16].

HT-29 cells were seeded $\left(5 \times 10^{4} \mathrm{cell} / \mathrm{ml}\right)$ in 96 well flat-bottom plates. After $24 \mathrm{~h}$ of incubation, HT-29 cells were treated, in quadruplicate, with increasing concentrations of leaf extracts or vehicle control and incubated for $24 \mathrm{~h}$. Subsequently, $20 \mu \mathrm{l}$ of MTS solution was added directly to culture wells and after $4 \mathrm{~h}$ of incubation the absorbance at $450 \mathrm{~nm}$ with a 96-well plate reader (MULTISKAN EX, Thermo Electron Corporation, Vantaa, Finland) was recorded.

\subsubsection{Cell viability}

The Trypan blue exclusion method is used to determine the number of viable cells in a cell suspension. The assay is based on the principle that dye passes only through the permeabilized membranes of dead cells. Briefly, after $24 \mathrm{~h}$ of treatment with $500 \mu \mathrm{g} / \mathrm{ml}$ leaf chloroform extract, cells were trypsinized and resuspended in DMEM; a 1:1 dilution of the cell suspension was obtained using a $0.4 \%$ trypan blue solution (BioWhittake ${ }^{\circledR}$, Lonza). The dilution was loaded on a counting chamber of a haemocytometer in order to evaluate the percentage of viable cells [17].

\subsubsection{Genotoxicity}

Alkaline comet assay was performed according to standard methods [18] with minor modifications. DNA damage was evaluated on HT-29 cell line. Cells were seeded at $4 \times 10^{5}$ cell $/ \mathrm{ml}$ in 6-well plates in DMEM supplemented with $1 \%$ glutamine, $0.5 \%$ penicillin/streptomycin and $10 \%$ foetal bovine serum. After seeding (24h), cells were treated with a range of concentrations of leaf chloroform extract $(0.5 \div 10$ $\mu \mathrm{g} / \mathrm{ml}$ ) that did not induce high cytotoxicity (viability $>70 \%$ ). After $24 \mathrm{~h}$ of incubation at $37^{\circ} \mathrm{C}$, cells were trypsinized and resuspended in DMEM at a concentration of $5 \times 10^{4} \mathrm{cell} / \mathrm{ml}$; the suspensions were centrifuged $(1 \mathrm{~min}, 800 \mathrm{~g})$ to recover the cells and the cell pellets were resuspended in $90 \mu \mathrm{l}$ Low Melting Agarose 0.7\% (LMA), transferred onto degreased microscope slides previously dipped in $1 \%$ Normal Melting Agarose (NMA) for the first layer. The agarose was allowed to set for $15 \mathrm{~min}$ at $4^{\circ} \mathrm{C}$ before the addition of a final layer of LMA. Cell lysis was carried out at $4^{\circ} \mathrm{C}$ overnight by exposing the cells to a buffer containing $2.5 \mathrm{M} \mathrm{NaCl}, 100 \mathrm{mM}$ $\mathrm{Na}_{2}$ EDTA, $8 \mathrm{mM}$ Tris- $\mathrm{HCl}, 1 \%$ Triton $\mathrm{X}-100$ and $10 \%$ DMSO, pH 10 . The electrophoretic migration was performed in an alkaline buffer (1 $\mathrm{mM} \mathrm{Na} \mathrm{EDTA}, 300 \mathrm{mM} \mathrm{NaOH}, 0^{\circ} \mathrm{C}$ ) at $\mathrm{pH}>13$ (DNA unwinding: $20 \mathrm{~min}$; electrophoresis: 20 min, $0.78 \mathrm{Vcm}-1,300 \mathrm{~mA})$. DNA was stained with $75 \mu \mathrm{l}$ ethidium bromide $(10 \mu \mathrm{g} / \mathrm{ml})$ before the examination at $400 x$ magnification under a Leica DMLS fluorescence microscope (excitation filter BP 515-560 nm, barrier filter LP $580 \mathrm{~nm}$ ), using an automatic image analysis system (Comet Assay III- Perceptive Instruments Ltd, UK). Tail fluorescence percentage ( $\mathrm{TI}$, tail intensity) and DNA migration (TL, tail length) provided representative data on DNA damaging effects. For each sample, coded and evaluated blind, 100 cells were analyzed and the median values (+SD) of $\mathrm{TI}$ and $\mathrm{TL}$ were calculated. Nuclei with a completely disintegrated head region, named hedgehogs, were only registered as percentage (GC, ghost cell).

\subsubsection{Oxidative DNA damage assay}

A modified protocol of the Comet assay was used to study the antioxidant effect of the extracts [19]. The amount of DNA damage caused by an oxidative damage-inducing agent on cells pre-treated or not with leaf chloroform extract was evaluated. Cells were seeded at $4 x$ $10^{5} \mathrm{cell} / \mathrm{ml}$ in 6-well plates in DMEM supplemented with $1 \%$ glutamine, $0.5 \%$ penicillin/streptomycin and $10 \%$ foetal bovine serum. After seeding (24 h), HT-29 cells were incubated with the extract $(5 \mu \mathrm{g} / \mathrm{ml})$ or with a known antioxidant agent, vitamin C $(1 \mathrm{mM})$, and incubated for 24h. After incubation, the cells were trypsinized and resuspended in DMEM (supplemented with $1 \%$ glutamine, $0.5 \%$ penicillin/streptomycin and $10 \%$ foetal bovine serum) at a concentration of $1 \times 10^{5} \mathrm{cell} / \mathrm{ml}$ for a further treatment in suspension, before perform Comet assay, with $100 \mu \mathrm{M}$ hydrogen peroxide $\left(\mathrm{H}_{2} \mathrm{O}_{2}\right)$ on ice for $5 \mathrm{~min}$. After this, the 
suspensions were centrifuged twice $(1 \mathrm{~min}, 800$ g) to wash and recover the cells. The slides were prepared and analyzed as reported above.

\subsection{Statistical Evaluation}

The data were analyzed using the statistical and graphical functions of SPSS 18 (SPSS Inc., Chicago, IL, USA). Differences were assessed using analysis of variance (ANOVA), followed by Bonferroni's post-hoc test as appropriate. Moreover, the Pearson's correlation coefficient of various data set about the in vitro antioxidant activity was calculated to assess their dependence. Significance was accepted at $\mathrm{p}=.05$ level.

\section{RESULTS}

\subsection{In vitro Antioxidant Activity}

Free radical scavenging properties of leaf different extracts of Citrullus colocynthis Schrad., expressed as $I_{50}(\mu \mathrm{g} / \mathrm{ml})$ for the DPPH and the reducing power assay and as inhibition percent (\%) for the $\beta$-carotene/linoleic acid test, are given in Table 1. Free radical DPPH scavenging activity and reducing power assay of the extracts are concentration dependent. The most polar extract (methanol extract) was able to reduce the stable free radical 2,2-diphenyl-1-picrylhydrazyl (DPPH) to the yellow-coloured diphenylpicryIhydrazine with an $\mathrm{IC}_{50}$ of $113.366 \mu \mathrm{g} / \mathrm{ml}$, to reduce the $\mathrm{Fe}^{3+}$ to $\mathrm{Fe}^{2+}$ with an $\mathrm{IC}_{50}$ of 124.173 $\mu \mathrm{g} / \mathrm{ml}$ and to exhibit a linoleic acid oxidation inhibition of $31.916 \%$ in the $\beta$-carotene/linoleic acid test. On the other hand, petroleum ether and chloroform extracts showed the lower antioxidant activities.

Dependence of these in vitro antioxidant assays data sets was characterized by calculating their Pearson's correlation $\left(R_{P}\right)$ dividing the covariance of the two variables by the product of their standard deviations. The Pearson's correlation value is between -1 and 1 indicating the degree of linear dependence between the variables as well as the positive or negative nature of dependence. The closer the coefficient is to either -1 or 1 the stronger the correlation between the variables.

Our results pointed out a significant strong and positive correlation $\left(R_{P}=.956\right)$ between $\mathrm{DPPH}$ assay and reducing power assay. Otherwise, we observed a significant strong and negative correlation between DPPH assay and $\beta$-carotene/linoleic acid test $\left(R_{P}=-.903\right)$ and between reducing power assay and $\beta$-carotene/linoleic acid test $\left(R_{P}=-891\right)$.

\subsection{Cytotoxic and Antiproliferative Effects}

Proliferation of HT-29 cells was significantly inhibited by Citrullus colocynthis leaf extracts in a dose-dependent manner. Antiproliferative activity was expressed as the concentration able to inhibit of $50 \%$ cells growth $\left(\mathrm{IC}_{50}\right)$. Based on the $\mathrm{IC}_{50}$ values (Fig. 1), the inhibitory effects of the leaf extracts on HT-29 cell proliferation are in the decreasing order: acetone extract $(368 \mu \mathrm{g} / \mathrm{ml})>$ petroleum ether extract $(355 \mu \mathrm{g} / \mathrm{ml})>$ methanol extract $(348 \mu \mathrm{g} / \mathrm{ml})>$ ethyl acetate extract $(296$ $\mu \mathrm{g} / \mathrm{ml})>$ chloroform extract $(160 \mu \mathrm{g} / \mathrm{ml})$.

In order to distinguish between a cytotoxic or cytostatic effect of the chloroform extract, the most antiproliferative one, we evaluated the number of viable cells (Trypan Blue exclusion method) after a 24h treatment at the highest tested concentration $(500 \mu \mathrm{g} / \mathrm{ml})$ and we observed a cytotoxic effect.

In addition, preliminary data (data not reported) on HT-29 cell line, after a treatment of $24 \mathrm{~h}$ with the leaf chloroform extract $(500 \mu \mathrm{g} / \mathrm{ml})$, suggest the apoptosis pathway involvement.

Table 1. In vitro antioxidant activity of Citrullus colocynthis leaf extracts

\begin{tabular}{llll}
\hline Extract & $\begin{array}{l}\text { DPPH scavenging activity } \\
\left(\mathbf{I C}_{50}\right)\end{array}$ & Reducing power $\left.\mathbf{( I C}_{50}\right)$ & $\begin{array}{l}\boldsymbol{\beta} \text {-carotene/ linoleic acid } \\
\text { test }(\%)\end{array}$ \\
\hline PE & $239.82 \pm 5.48$ & $478.10 \pm 25.51$ & $19.98 \pm 0.17$ \\
Chl & $202.88 \pm 2.82$ & $461.69 \pm 20.05$ & $20.77 \pm 0.39$ \\
EA & $180.69 \pm 1.77$ & $392.62 \pm 2.59$ & $21.48 \pm 0.62$ \\
A & $128.94 \pm 0.48$ & $134.17 \pm 2.54$ & $25.88 \pm 1.07$ \\
M & $113.37 \pm 0.58$ & $124.27 \pm 3.51$ & $31.92 \pm 2.30$ \\
Q & $1.04 \pm 0.01$ & $2.32 \pm 0.09$ & $55.89 \pm 1.45$ \\
BTH & $4.40 \pm 0.10$ & $7.35 \pm 0.13$ & $89.00 \pm 2.07$ \\
\hline \multicolumn{2}{c}{${ }^{*} P E:$ Petroleum ether; Chl: Chloroform; EA: Ethyl acetate; A: Acetone; M: Methanol; Q: Quercetine; BHT }
\end{tabular}




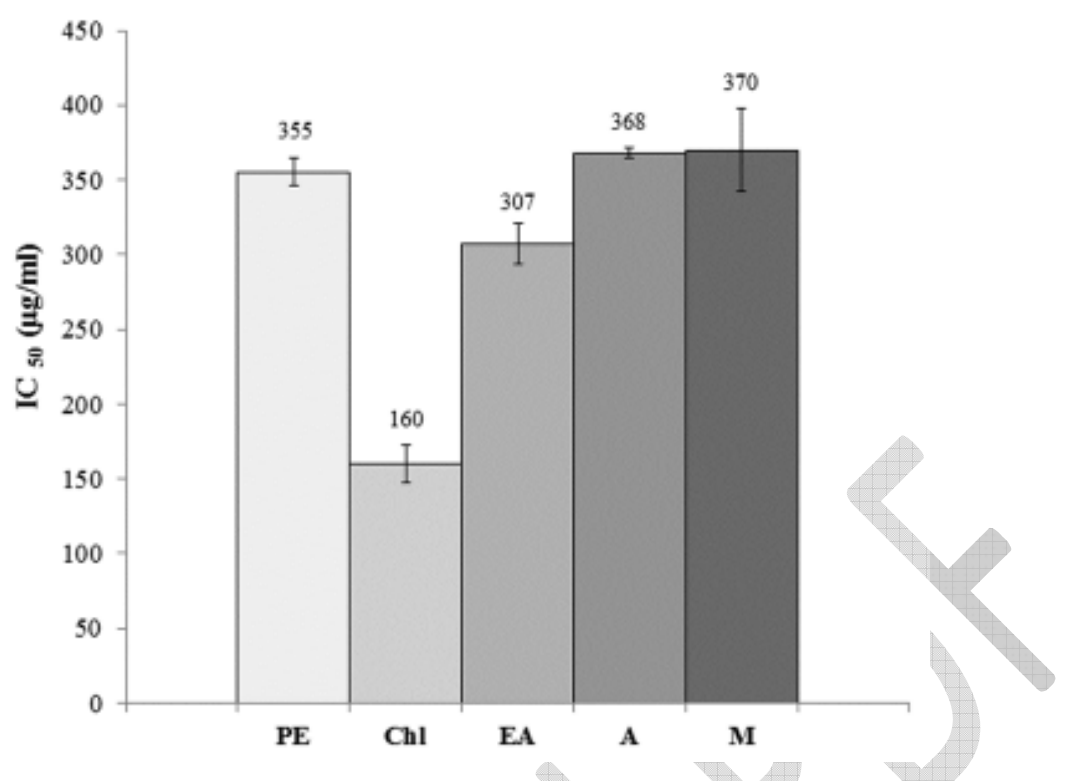

Fig. 1. Antiproliferative effect of Citrullus colocynthis on HT-29 after 24h in vitro treatment with different leaf extracts $(0.5 ; 5.0 ; 50.0 ; 500.0 \mu \mathrm{g} / \mathrm{ml})$

$I C_{50}: 50 \%$ cell growth inhibitory concentration

PE: Petroleum ether; Chl: Chloroform; EA: Ethyl acetate; A: Acetone; M: Methanol.

Mean \pm S.D. $=$ Mean values \pm Standard deviation of means of three experiments

\subsection{Genotoxicity}

Genotoxicity was measured using single-cell gel electrophoresis (Comet assay) in the alkaline version $(\mathrm{pH}>13)$. This assay detects singlestrand breaks and alkali-labile sites, such as apyrimidinic and apurinic sites, that are formed when bases are lost, and oxidized bases. Chloroform leaf extract did not induce any DNA damage on HT-29 cell after 24h treatment (Table 2).

\subsection{Oxidative DNA Damage Protection}

The antioxidant activity of chloroform leaf extract was evaluated on $24 \mathrm{~h}$ pre-treated HT-29 cell line as reduction of DNA migration induced by $\mathrm{H}_{2} \mathrm{O}_{2}$.

The extract showed a significant decrease of DNA damage induced by $\mathrm{H}_{2} \mathrm{O}_{2}$ (Fig. 2). In particular at $5 \mu \mathrm{g} / \mathrm{ml}$ the chloroform leaf extract presented a protective antioxidant activity comparable to that of vitamin C (1 mM) (Fig. 2).

\section{DISCUSSION}

Traditional medical information could be a successful starting point to develop new anticancer strategies. Some worldwide used drugs employed in chemotherapy were isolated from plants that grow in particular environments such as taxol from the Pacific yew tree; camptothecin from the Chinese "happy tree" Camptotheca acuminata and combretastatin, from the South African bush willow [20]. The potential of ethno-drugs as to be proven with stringent scientific approach. Citrullus colocynthis Schrad. is an interesting traditional medicinal plant that showed different biological activities. In this study, we tried to evaluate the ability of C. colocynthis leaf extracts to control colon cancer cell proliferation in relation to their antioxidant properties.

During the common cellular pathways there is a physiological release of reactive oxygen/nitrogen species (ROS/RNS), such as superoxide radical, hydrogen peroxide, singlet oxygen and hydroxyl radical, involved in mechanisms such as energy supply, detoxification and signalling. Endogenous antioxidant mechanisms, including enzymatic defences, contribute to their efficient removal. When they fail, free radicals induce an oxidative damage. These oxidative species are known to lead to DNA, lipid and protein damage compromising cellular processes such as proliferation, apoptosis and senescence [21,22]. Consequently, exposure to free radicals potentially increases the risk of a wide array of human diseases, such as cardiovascular diseases and cancer. For this reason there is a continuous search for new medical preparations to counteract the effects of oxidative stress. 
Table 2. Tail fluorescence percentage (TI, tail intensity), DNA migration (TL, tail length) and Ghost cell (GC) percentage detected by Comet assay on HT-29 after 24h in vitro treatment with the chloroform leaf extract

\begin{tabular}{llll}
\hline $\begin{array}{l}\text { Extract concentration } \\
(\boldsymbol{\mu g} / \mathrm{ml})\end{array}$ & $\begin{array}{l}\text { TI } \\
(\%)\end{array}$ & $\begin{array}{l}\text { TL } \\
(\boldsymbol{\mu m})\end{array}$ & $\begin{array}{l}\text { GC } \\
(\%)\end{array}$ \\
\hline 0.0 & $0.14 \pm 0.01$ & $18.58 \pm 4.70$ & $3.5 \pm 0.71$ \\
0.5 & $0.51 \pm 0.10$ & $21.26 \pm 1.60$ & $14.5 \pm 3.54$ \\
1.0 & $0.42 \pm 0.27$ & $21.26 \pm 2.07$ & $8.5 \pm 2.12$ \\
5.0 & $0.32 \pm 0.03$ & $18.83 \pm 1.03$ & $6.5 \pm 2.83$ \\
10.0 & $0.27 \pm 0.01$ & $17.93 \pm 0.34$ & $7.0 \pm 0.01$ \\
\hline
\end{tabular}

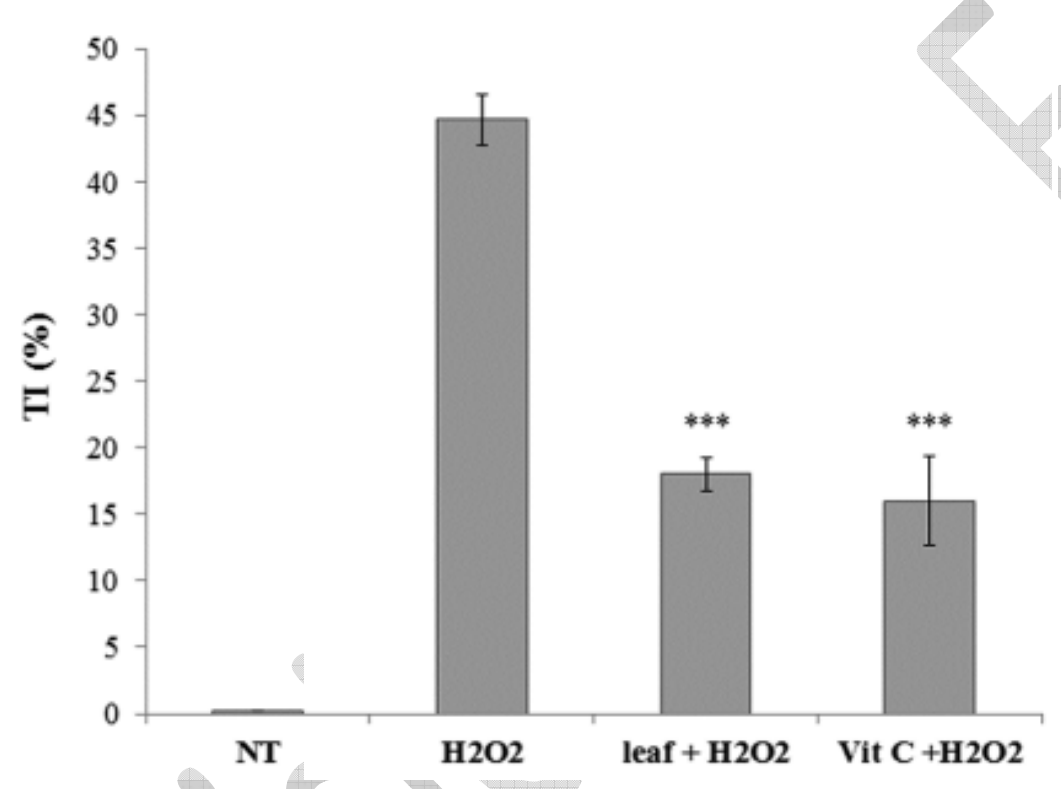

Fig. 2. Antioxidant activity of leaf chloroform extract $(5 \mu \mathrm{g} / \mathrm{ml})$ or vitamin $\mathrm{C}(1 \mathrm{mM})$ detected by comet assay on 24h pre-treated $\mathrm{HT} 29$ cell line as reduction of DNA migration induced by $\mathrm{H}_{2} \mathrm{O}_{2}$. $T I(\%)$ : tail fluorescence percentage.

Vegetables contain, in addition to vitamins and minerals, many microconstituents, such as carotenoids, glucosinolates, indoles, isothiocyanates, etc. These compounds are now recognized as being biologically active thanks to their ability to supplement cellular defence systems, in particular they showed a high ability to counteract the oxidative stress [23].

In many cases the exact composition and the bioavailability of active molecules is not known. Furthermore, the content of beneficial molecules varies with genetic strain, growth and storage conditions of the plant. For this reason assessing the true impact of such constituents on human health could be difficult.

Several assays are used for the evaluation of the antioxidant activities, these methods were applied to quench and scavenge reactive oxygen species, which comprise both free radicals $\left(\mathrm{O}_{2}{ }^{\bullet-}\right.$, $\mathrm{OH} \cdot, \mathrm{HO}_{2} \cdot$, and $\mathrm{RO} \cdot$ ) and non-radical (molecular) forms $\left(\mathrm{H}_{2} \mathrm{O}_{2}\right.$ and $\left.{ }^{1} \mathrm{O}_{2}\right)$ [24]. Numerous analyses such as total antioxidant activity, DPPH and ABTS assays, ROS quenching assay, metal chelating, reductive potential, $\beta$-carotene linoleate system and linoleic acid method are the most commonly used for the determination of antioxidant activities of plant extracts [25]. These assays are able to detect the three major mechanisms by which antioxidants can deactivate radicals: Hydrogen atom transfer (HAT), electron transfer (ET) and combination of both HAT and ET [26]. While HAT measures the ability of an antioxidant to quench free radicals by hydrogen donation, ET detects the ability of antioxidant to transfer one electron to reduce radicals, metals and carbonyls [27]. Majer [28] found that the different methods used to determine the antioxidant activity are not 
interchangeable and sometimes they are not in correlation because antioxidants may have a different reactivity in the various methods. Nevertheless, in our study, we find a good correlation among in vitro assays: A significant strong and positive correlation between DPPH and reducing power assay and a significant strong and negative correlation between them and $\beta$-carotene/linoleic acid test. Since the $\mathrm{DPPH}$ assay detect both hydrogen atom and electron transfer, the reducing power assay detects only electron transfer and $\beta$ carotene/linoleic acid test only hydrogen atom transfer, the dependency relationship among these in vitro antioxidant assays suggest that Citrullus colocynthis Schrad. leaves, namely polar extracts (acetone and methanol ones), have in vitro antioxidant properties acting as electron donors.

The antioxidant activity of leaf extracts, observed in HT-29 cell line, didn't correlate with in vitro results. The methanol extract, the in vitro most active one, isn't the more effective on cells. On the contrary the chloroform extract, one of the less active in vitro, is the one that induces the higher cell response. Furthermore, it has shown an antioxidant in vivo activity on $\mathrm{HT}-29$ cell line at $5 \mu \mathrm{g} / \mathrm{ml}$, that is a concentration tenfold lower than the in vitro active one $(50 \mu \mathrm{g} / \mathrm{ml}$, data not shown) and much lower than the antiproliferative one $(160 \mu \mathrm{g} / \mathrm{ml})$.

This behaviour underlines a complex relationship between antioxidant activity and inhibition of proliferation. The antioxidant concentration, detected by Comet assay, seems to re-establish cell homeostasis since a cell proliferation variation isn't evidenced. On the contrary, higher extract concentrations result in a remarkable ROS depletion in cells, that can culminate in a cytotoxic effect as suggested by the oxidative balance under which a high reduction in intracellular ROS levels can induce a decrease in cell proliferation [29].

Antioxidant and antiproliferative activities of C. colocynthis leaf polar extracts could be related to the presence of phenolic compounds. In a previous paper [4], reporting the anticandidal and antibacterial effects of aqueous and acetonewater extracts, we showed that only leaves posses a content of coumarins and tannins among the different plant organs.

Furthermore, recently Chawech et al. [30] identified two new tetracyclic cucurbitane-type glycosides together with four known cucurbitacins, derived from an ethyl acetate leaf extract. Some of them showed a peculiar antiproliferative activity on colorectal cell lines (HT29 and Caco-2) without cytotoxic effects on mammalian normal cells. Cucurbitacin glucosides are known being able to scavenge hydroxyl radical, superoxide anion, and singlet oxygen ${ }^{7}$. Moreover, their antiproliferative action on human breast cancer cells increases when they are tested in combination [11], indicating that the complex relationship between the molecules present in the phytocomplex has to be taken into account when evaluating the biological activities of leaf extracts and, in a broader perspective, on vegetable extract in general.

\section{CONCLUSION}

In conclusion, our data confirm that Citrullus colocynthis Schrad fitocomplex could be an important source of natural atiproliferative agents. Furthermore, our study can be considered as a report on the complex relationships existing between antioxidant and antiproliferative properties of extracts prepared from Citrullus colocynthis Schrad. leaves. Pending further analysis and experimentation, these natural extracts may have potential applications in the food and pharmaceutical industries.

\section{CONSENT}

It is not applicable.

\section{ETHICAL APPROVAL}

It is not applicable.

\section{COMPETING INTERESTS}

Authors have declared that no competing interests exist.

\section{REFERENCES}

1. Pravin B, Deshmukh $T$, Vijay $P$, Kishanchnad K. Review on Citrullus colocynthis. Int. J. Res. Pharm. Chem. 2013;3(1):46-53.

2. Rhamatullah M, Biswas A, Haq WM, Seraj $S$, Jahan $R$. An ethnomedicinal survey of cucurbitaceae family plants used in folk medicinal practices of Bangladesh. Chronicles Young Sci. 2012;3:212-222. 
3. Bendjeddou D, Lalaoui K, Satta D. Immunostimulating activity of the hot water-soluble polysaccharide extracts of Anacyclus pyrethrum, Alpinia galanga and Citrullus colocynthis. J. Ethnopharmacol. 2003;88(2-3):155-160.

4. Marzouk B, Marzouk Z, Décor R, Edziri H, Haloui E, Fenina N, Aouni M. Antibacterial and anticandidal screening of Tunisian Citrullus colocynthis Schrad. from Medenine. J. Ethnopharmacol. 2009; 125(2):344-349.

5. Marzouk B, Marzouk Z, Haloui E, Fenina $N$, Bouraoui A, Aouni M. Screening of analgesic and anti-inflammatory activities of Citrullus colocynthis from southern Tunisia. J. Ethnopharmacol. 2010;128(1): 15-19.

6. Jayaprakasam B, Seeram NP, Nair MG. Anticancer and antiinflammatory activities of cucurbitacins from Cucurbita andreana. Cancer Lett. 2003;189(1):11-16.

7. Tannin-Spitz T, Bergman M, Grossman S. Cucurbitacin glucosides: Antioxidant and free-radical scavenging activities. Biochem. Biophys. Res. Commun. 2007; 364(1):181-186.

8. Gebhardt R. Antioxidative, antiproliferative and biochemical effects in HepG2 cells of a homeopathic remedy and its constituent plant tinctures tested separately or in combination. Arzneimittelforschung. 2003; 53(12):823-830.

9. Al-Ghaithi F, El-Ridi MR, Adeghate E, Amiri $\mathrm{MH}$. Biochemical effects of Citrullus colocynthis in normal and diabetic rats. Mol. Cell. Biochem. 2004;261(1-2):143149.

10. Blaskovich MA, Sun J, Cantor A, Turkson J, Jove R, Sebti SM. Discovery of JSI-124 (cucurbitacin I), a selective Janus kinase/ signal transducer and activator of transcription 3 signaling pathway inhibitor with potent antitumor activity against human and murine cancer cells in mice. Cancer Res. 2003;63(6):1270-1279.

11. Tannin-Spitz T, Grossman S, Dovrat S, Gottlieb HE, Bergman M. Growth inhibitory activity of cucurbitacin glucosides isolated from Citrullus colocynthis on human breast cancer cells. Biochem. Pharmacol. 2007; 73(1):56-67.

12. Pottier Alapetite G. Flore de la Tunisie. Angiospermes-dicotylédones, gamopetales. Programme flore et Végétation Tunisiennes; 1981.
13. Burits M, Bucar F. Antioxidant activity of Nigella sativa essential oil. Phytother. Res. 2000;14(5):323-328.

14. Oyaizu M. Studies on products of browning reaction antioxidative activities of products of browning reaction prepared from glucosamine. Japanese J. Nutr. Diet. 1986;6:307-315.

15. Miraliakbari $H$, Shahidi F. Antioxidant activity of minor components of tree nut oils. Food Chem. 2008;111(2):421-427.

16. Cory AH, Owen TC, Barltrop JA, Cory JG. Use of an aqueous soluble tetrazolium/ formazan assay for cell growth assays in culture. Cancer Commun. 1991;3(7):207212.

17. Strober W. Trypan blue exclusion test of cell viability; 2001. (Appendix 3).

18. Singh NP, McCoy MT, Tice RR, Schneider EL. A simple technique for quantitation of low levels of DNA damage in individual cells. Exp. Cell Res. 1988;175(1):184-191.

19. Ferrarini L, Pellegrini N, Mazzeo T, Miglio C, Galati S, Milano F, Rossi C, Buschini A. Anti-proliferative activity and chemoprotective effects towards DNA oxidative damage of fresh and cooked Brassicaceae. Br. J. Nutr. 2012;107(9): 1324-1332.

20. Brower V. Back to nature: Extinction of medicinal plants threatens drug discovery. J. Natl. Cancer Inst. 2008;100(12):838839.

21. Waris G, Ahsan $H$. Reactive oxygen species: Role in the development of cancer and various chronic conditions. J. Carcinog. 2006;5:1-8.

22. Klaunig JE, Kamendulis LM, Hocevar BA. Oxidative stress and oxidative damage in carcinogenesis. Toxicol. Pathol. 2010;38(1):96-109.

23. Slavin JL, Lloyd B. Health Benefits of Fruits and Vegetables. Adv. Nutr. An Int. Rev. J. 2012;3(4):506-516.

24. Gill SS, Tuteja N. Reactive oxygen species and antioxidant machinery in abiotic stress tolerance in crop plants. Plant Physiol. Biochem. 2010;48(12):909-930.

25. Ksouri R, Falleh $H$, Megdiche W, Trabelsi $\mathrm{N}$, Mhamdi B, Chaieb K, Bakrouf A, Magné C, Abdelly C. Antioxidant and antimicrobial activities of the edible medicinal halophyte Tamarix gallica $\mathrm{L}$. and related polyphenolic constituents. Food Chem. Toxicol. 2009; 47(8):2083-2091. 
26. Prior RL, Wu X, Schaich K. Standardized methods for the determination of antioxidant capacity and phenolics in foods and dietary supplements. J. Agric. Food Chem. 2005;53(10):4290-4302.

27. Huang D, Ou B, Prior RL. The chemistry behind antioxidant capacity assays. J. Agric. Food Chem. 2005;53(6):1841-1856.

28. Majer P, Stoyanova S, Hideg E. Do leaf total antioxidant capacities (TAC) reflect specific antioxidant potentials? - A comparison of TAC and reactive oxygen scavenging in tobacco leaf extracts. J. Photochem. Photobiol. B. 2010;100(1): 38-43.

29. Finkel T, Holbrook NJ. Oxidants, oxidative stress and the biology of ageing. Nature. 2000;408(6809):239-247.

30. Chawech R, Jarraya R, Girardi C, Vansteelandt M, Marti G, Nasri I, RacaudSultan C, Fabre N. Cucurbitacins from the Leaves of Citrullus colocynthis (L.) Schrad. Molecules. 2015;20(10):18001-18015.

(c) 2016 Marzouk et al.; This is an Open Access article distributed under the terms of the Creative Commons Attribution License (http://creativecommons.org/licenses/by/4.0), which permits unrestricted use, distribution, and reproduction in any medium, provided the original work is properly cited.

Peer-review history:

The peer review history for this paper can be accessed here: http://sciencedomain.org/review-history/13125 